\title{
Slope failure on a Cambrian carbonate platform, mass-flow transitions and resulting complex deposit
}

\author{
Zhaopeng WANG ${ }^{1}$, Jiaye LIU ${ }^{1}$, A.J. (Tom) VAN LOON ${ }^{1}$, Decheng $\mathrm{ZHU}^{3,4}$, \\ Peng QIN ${ }^{5}$ and Zuozhen HAN ${ }^{1,2, *}$
}

1 Shandong University of Science and Technology, Shandong Provincial Key Laboratory of Depositional Mineralization and Sedimentary Minerals, No. 579 Qianwangang Road, Qingdao, Shandong 266590, China

2 Qingdao National Laboratory for Marine Science and Technology, Laboratory for Marine Mineral Resources, No. 1 Wenhai Road, Qingdao 266237, China

3 Ministry of Land and Resources of the People's Republic of China, Key Laboratory of Gold Mineralization Processes and Resources Utilization, No. 52 Lishan Road, Jinan 250013, China

4 Key Laboratory of Geological Mineralization Processes of Metals and Resource Utilization in Shandong Province, No. 52 Lishan Road, Jinan 250013, China

5 Shandong Geological Environmental Monitoring, No. 17 Jishan Road, Jinan 250013, China

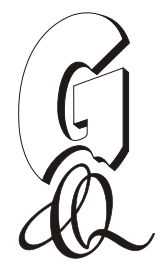

Wang, Z., Liu, J., Van Loon, A.J. (Tom), Zhu, D., Qin, P., Han, Z., 2020. Slope failure on a Cambrian carbonate platform, mass-flow transitions and resulting complex deposit. Geological Quarterly, 64 (1): 3-15, doi: 10.7306/gq.1517

The quiet environment of the carbonate platform in the epeiric sea that existed during the Cambrian between present-day China and Korea was occasionally affected by processes that have hitherto not been described from such a setting. A conglomerate was found in the Middle Cambrian Gushan Formation near Chengouwan (Shandong Province, E China), eroded into the underlying sediments. The conglomerate is explained as a deposit consisting of material that was eroded up-slope when slope-failure took place, resulting in a slump that passed into a high-density debris flow with erosive power that passed, in turn, again into a slump. The slump came to rest when it lost its momentum on a less inclined part of the basin slope. Immediately after deposition, fluidization occurred in the lower part of the slump deposit, as proven by a funnel-shaped water-escape structure and a lateral injection of some metres long of brecciated material.

Key words: Gushan Formation, Middle Cambrian, epeiric sea, carbonate platform, mass-flow transitions.

\section{INTRODUCTION}

Carbonate platforms that developed in ancient epeiric seas commonly represent quiet conditions that continued for a long time. The sediments tend consequently to be very continuous over hundreds of metres to several kilometres, so that they can be correlated from section to section. The most common events that interrupted the quiet conditions were heavy storms that induced waves which could break-up thin limestone beds either on the seafloor or intrastratally (under a thin cover of sediment) due to cyclic loading of storm waves, thus giving rise to limestone breccias that often can be traced over long distances (Chen et al., 2009a, 2011). Apart from such storms and from truly exceptional events such as meteorite impacts or tsunamis, only biological activity is commonly considered to have been capable of interrupting the commonly relatively quiet sedimen-

\footnotetext{
* Corresponding author, e-mail: hanzz@163.com
}

Received: June 12, 2019; accepted: October 9, 2019; first published online: February 27, 2020 tary development of carbonate platforms. This does not imply, however, that processes able to affect the sediment were absent during such "quiet" conditions. Currents, caused either by wind or by ocean current, were present, as indicated by the presence of inclined lamination representing the foresets of $\mathrm{cm}$-sized current ripples. Larger, dm-sized, may represent stronger currents induced by storm activity. Also waves, and occasionally storm waves, must have been part of these "quiet" conditions.

Although the quiescence of the epeiric seas consequently was certainly not outspoken from a climatic and sedimentological point of view, tectonic quiescence is commonly presumed to have dominant for long times. Fault activity tended to be rare, in spite of the fact that the thick successions (often hundreds of metres) of sediments deposited in shallow water (above storm wave base) could accumulate. This proves that basin subsidence took place at the same pace as sediment accumulation. The subsidence apparently occurred so gradually that, as a rule, no faulting resulted that might have led to significant height differences within the basin; neither did, as a rule, earthquakes occur of such a magnitude $\left(M_{w}>4.5-5\right)$ that might have resulted in liquefaction and deformation of the uppermost sedimentary layers. 


\section{SLOPE FAILURE}

Only in the past few years it has become clear that, in spite of the very gentle character of the slopes in this environment, mass transport could take place (e.g., García-Tortosa et al., 2011; Van Loon et al., 2012; Myrow and Chen, 2015). The present contribution deals with such a process that, though at a scale of only a few metres, took place in a hitherto not well-recognized form.

A great effort has been made in the past few decades to characterize and better understand recent seafloor failure on the margins of the Atlantic Ocean (e.g., Norway, eastern Brazil, eastern U.S.A., eastern Canada, Mexico; Mienert and Weaver, 2002; Locat and Mienert, 2003) and of the Pacific Ocean (e.g., western U.S.A., western Canada, French Polynesia, eastern Korea; Lee et al., 1991) by side-scan sonar and seismic images. Ten short-term and three long-term possible trigger mechanisms for the origin of the observed slope failures have been recognized by Sultan et al. (2004), who propose that earthquakes and storm waves are probably the most common causes of slope failure. Although the above studies of slope failure on ocean margins are not representative of epeiric seas, they provide insight into both the process (and cause) of slope failure and the transitions of gravity flows from one type into another; these data have been used in the present study to help analyse and interpret the processes and resulting deposition of the conglomerate mass that forms the subject of the present study.
The primary objectives of the present contribution are to describe the characteristics of the conglomerate, to reconstruct the various transport processes and their transitions, and to determine the genesis of the related structures. This objective is important because the transitions from one type of gravity flow into another are not only still understudied (Strachan, 2008) but also rarely described on the basis of field data.

Considering the fact that these processes and sediments are hardly - if at all - known form ancient carbonate platforms, the study is of interest for all earth scientists who are involved in the morphology, sedimentology or process dynamics that took place on carbonate platforms in the geological past - and that possibly also take place in the few comparable areas that exist nowadays.

\section{GEOLOGICAL SETTING}

The section under study (Fig. 1) is located near the village of Chengouwan, $\sim 70 \mathrm{~km} \mathrm{SSW}$ of the city of Jinan, Shandong Province (E China). The region forms part of the Luxi Block of the North China Platform. This platform was tectonically stable and covered a vast epeiric sea during the Paleozoic, with the exception of a few phases of minor uplift during the Middle Cambrian to Early Ordovician (Meng et al., 1997; Zhen et al., 2016; Yang et al., 2019).

\section{OBJECTIVE OF THE STUDY}

The Middle Cambrian Gushan Formation and the overlying Late Cambrian Chaomidian Formation on the North China Platform have received ever more attention in the past few decades. Particularly their biostratigraphy, sedimentology and sequence stratigraphy have been studied extensively (e.g., Lu et al., 1953; Wang et al., 1989; Mei et al., 1996), resulting in a detailed overall picture of their developments. Yet, new features are still discovered as fieldwork goes on. The present study focuses on the rare occurrence of a sedimentary unit that represents the consequences of slope failure that took place on the carbonate platform on which these formations accumulated. This unit consists of a deformed conglomerate with soft-sediment deformation structures, different types of clasts, a funnel-shaped escape structure and a lateral injectite extending for several metres.

Previous workers interpreted these conglomerates exclusively as subtidal storm deposits either by in situ rip-up and sedimentation by storm currents (or waves) or by storm-induced debris flows and turbidity currents (Tian et al., 1994; Wang, 1995; Meng et al., 1997). However, most of these conglomerates lack evidence of a storm origin such as normal or inverse grading cross-stratification and sharp erosional bases (Chen et al., 2009a). The present study examines the origin of an exceptional example of these conglomerates.

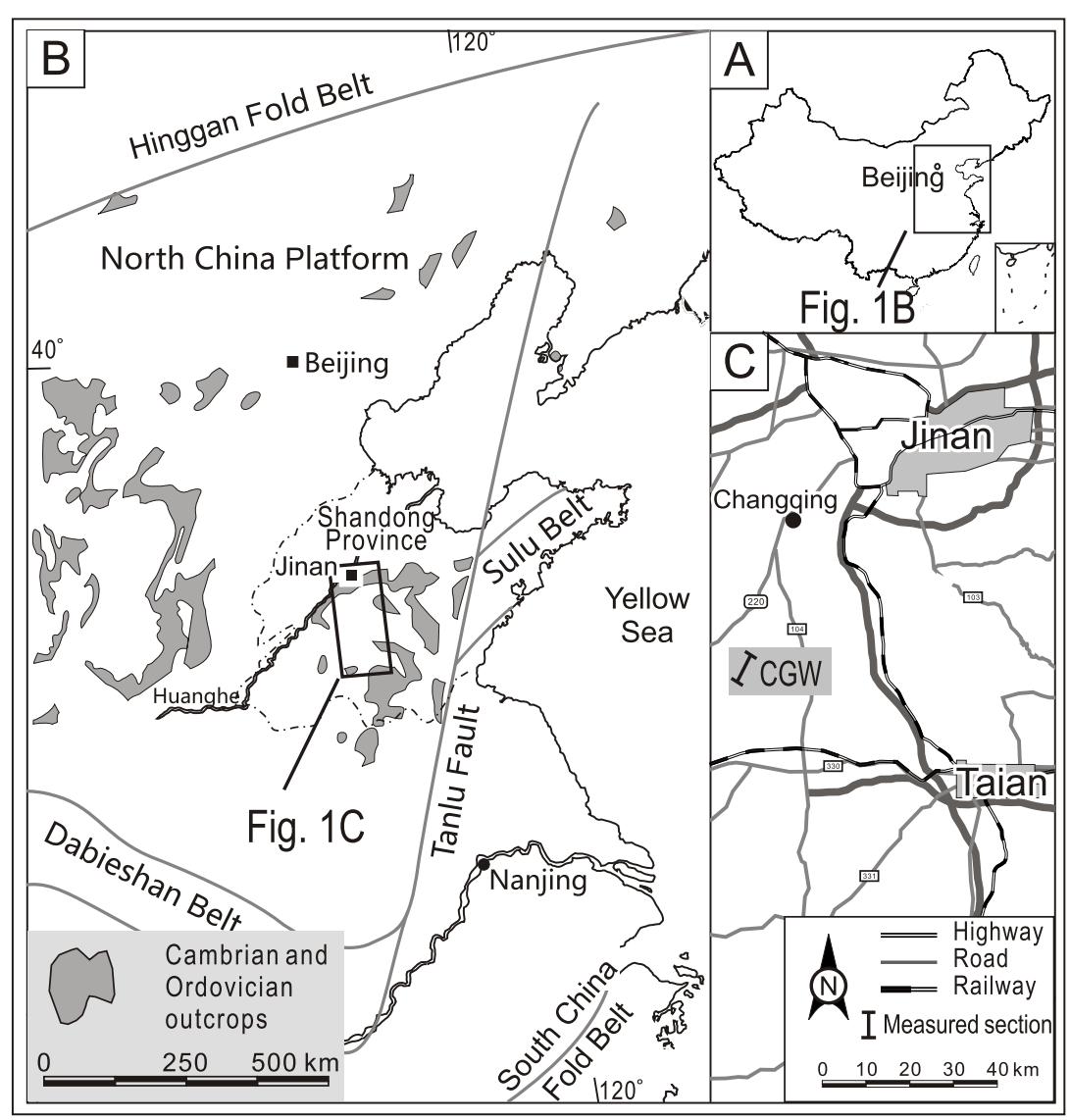

Fig. 1. Location maps

A - map of China with location of the Jinan area (Fig. 1B); B - map of the Jinan area with location of the study area (Fig. 1C); C - location of the section under study (CGW) in the Jinan area 


\section{PLATFORM CHARACTERISTICS}

The North China Platform developed during Cambrian Series 2 . The platform was almost totally submerged under the globally rising sea level, apart from some highlands that were exposed subaerially in the Ordos region during the Middle Cambrian (Series 3). The platform was dominated by a shallow-water facies, with frequently shifting supratidal, intertidal and subtidal zones (Chen et al., 2011, 2012; Lee and Chough, 2011). Sedimentation continued until the Middle Ordovician, resulting in a thick $(\sim 1800 \mathrm{~m})$ succession of mixed carbonates (lime-mudstones, wackestones to grainstones, microbialites) and siliciclastics (mainly mudstones) (Meng et al., 1997; Chough et al., 2010). The sediments show abundant soft-sediment deformation structures, probably partly due to storm-wave loading (Chen et al., 2009a, 2010; Chen and Lee, 2013; Chen, 2015), partly to the escape of over-pressurized water/sediment mixtures (Van Loon et al., 2013).

\section{STRATIGRAPHIC CONTEXT}

The Cambrian succession in Shandong consists of six lithostratigraphic units: these are, from old to young, the Liguan, Zhushadong, Mantou, Zhangxia, Gushan, and Chaomidian formations (Fig. 2). The Cambrian strata unconformably overlie Precambrian granitic gneiss or, locally, Late Proterozoic metasedimentary rocks, and are conformably over- lain by Ordovician dolostones (Sanshanzi Formation) (Chough et al., 2010; Fig. 2).

The basal Cambrian unit, the Liguan Formation, consists of quartzose sandstones and mudstones and is laterally discontinuous (Lee et al., 2018). The Zhushadong and Mantou formations are mainly composed of red mudstones interbedded with dolomites and evaporites (Lee and Chough, 2011). The Zhangxia Formation is dominated by widespread oolitic limestones, whereas its upper part and the overlying Gushan and Chaomidian formations are mainly composed of shales and subtidal carbonates with a variety of limestone conglomerates and breccias, as well as biohermal microbialites (Mei et al., 1997; Chough et al., 2010; Chen et al., 2011, 2014; Han et al., 2015; Ma et al., 2017). An extensive ( $100 \mathrm{~km})$ erosion surface of a strongly deformed limestone bed occurs in the uppermost part of the Gushan Formation, which is overlain by a bioclastic grainstone of the Chaomidian Formation (Chen et al., 2011).

\section{DEPOSITIONAL ENVIRONMENT OF THE GUSHAN FORMATION}

The Gushan Formation is mainly composed of shales and carbonates, dominated by greenish-gray to yellowish-gray shales, frequently intercalated with thin homogeneous lime-mudstone beds, forming limestone/shale alternations, representing subtidal low-energy environments that were occasionally disturbed by storms (Chen et al., 2011, 2012).

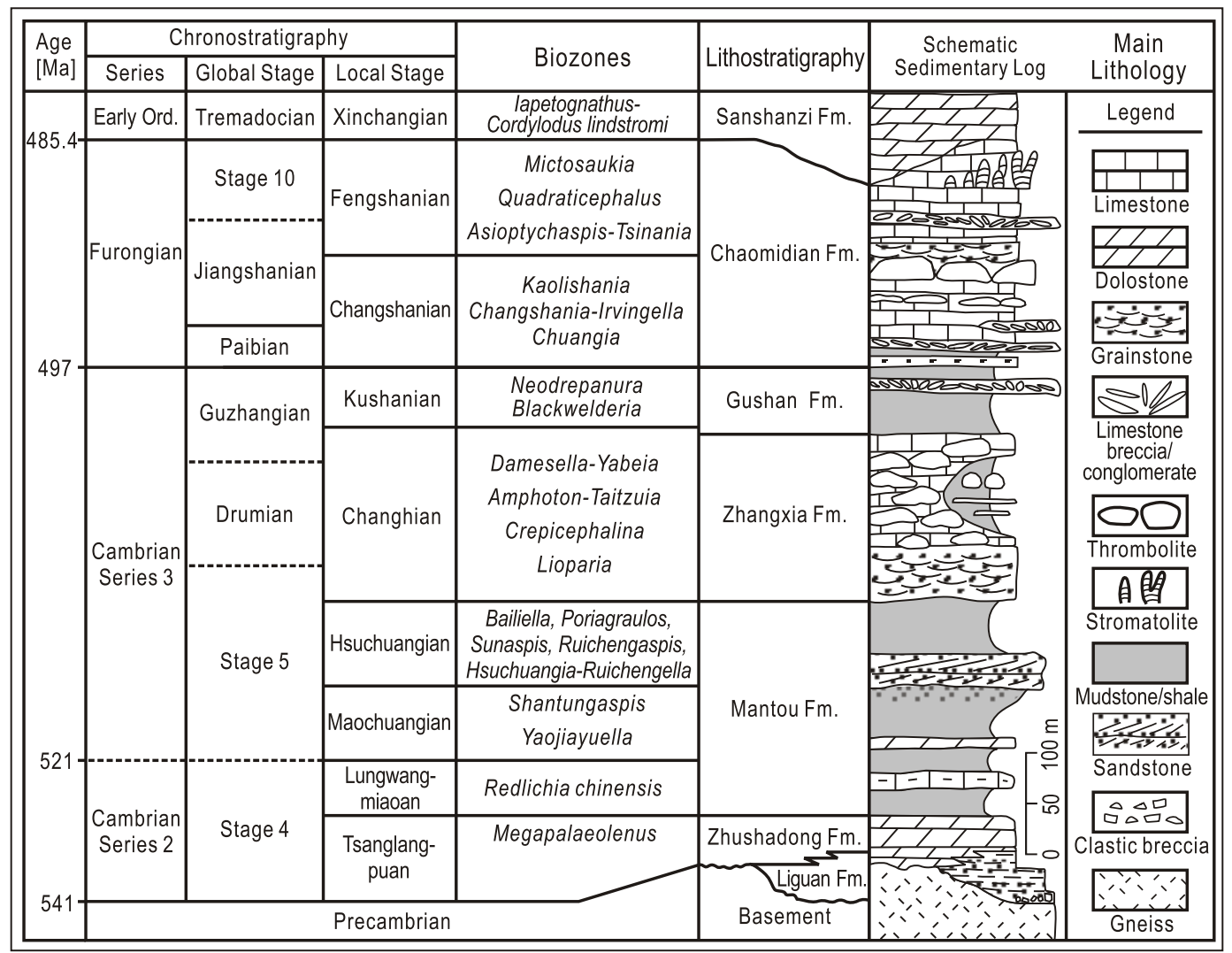

Fig. 2. Schematic stratigraphy of the Cambrian succession in Shandong Province, China (modified from Chen et al., 2011) 


\section{DESCRIPTION OF THE SEDIMENT UNDER STUDY}

The Gushan Formation in the Chengouwan section is $\sim 50 \mathrm{~m}$ thick. It is mainly composed of thin-bedded limestones, oolites, limestone conglomerates and shales. An exceptional feature is the erosion of a one-metre-thick succession by a conglomerate/breccia mass (called "conglomerate" in the following for the sake of brevity) of only $230 \mathrm{~cm}$ wide and $80 \mathrm{~cm}$ thick It is separated by a highly irregular boundary from the overlying oolitic limestone layer U8.

The succession eroded by the conglomerate consists of five units (Fig. 3). This succession rests on a flat-pebble conglomerate with lime-mudstone clasts (U1) and a thin-bedded peloidal grainstone (U2); these two units are relatively intact, not having been visibly eroded by the deformed conglomerate mass. The visibly eroded succession consists, from old to young, of a thin-bedded lime-mudstone and argillaceous lime-mudstone (U3), a layer with homogeneous and laminated clasts (U4), a laminated peloidal grainstone with thin shale intercalations (U5), a layer consisting of lime-mudstone clasts (U6), and a cross-stratified oolite (U7). The locally eroded succession of units U3 through U7 is overlain via a highly irregular boundary by a cross-stratified oolite with disconnected lime-mudstone intercalations (U8).

The conglomerate mass that erodes units U3 through U7 contains particles of mud size to boulder size that do not show any sorting (Figs. 4 and 5).

Four types of clasts are present (Table 1):

- homogeneous lime-mudstone clasts (LMC),

- oolite clasts (OC),

- clotted/brecciated wackestone clasts (CWC),

- conglomerate clasts (CC).

Differential early cementation of carbonate caused that oolites are present as clasts but that ooids are also present as matrix. The mixture of clasts with different compositions (Fig. 6 ), which is a feature not encountered elsewhere in the formation, represents an almost complete presence of the older types of sediments that are locally present in the Gushan Formation.

\section{POSITION WITHIN THE AUTOCHTHONOUS SEDIMENTS}

The eroded succession described above occurs in the uppermost part of the Gushan Formation, some three metres below the base of the Furongian Chaomidian Fm. The succession is laterally discontinuous and contains some small bioherms at a distance of only a few tens of metres away from the site under study. As the conglomerate mass flowed downslope to its present location, it merged with the unconsolidated layers U3 and U6 to form what is now the severely deformed mass; the exposure does not allow to see whether the underlying grainstone $\mathrm{U} 2$ has been eroded, but this cannot be excluded.

\section{ADDITIONAL FEATURES}

Two features are present that are directly connected with the conglomerate mass. They are funnel-shaped escape structure and a lateral injectite consisting of breccia.

Funnel-shaped structure - a funnel-shaped structure is present at the left-hand side of the conglomerate mass (Fig. 7). Its lowermost part is absent because a fissure at the side of the conglomerate mass has been widened by (probably weathering-enhanced) erosion, but the width at its lowest end is $\sim 1 \mathrm{~cm}$. The structure gradually widens upwards, reaching a maximum width of some $25 \mathrm{~cm}$ at its top. The funnel shape of the structure is particularly well-visible in its lower part (up to $\sim 20 \mathrm{~cm}$ from its lowest point) because erosion at both sides separates the structure from the adjoining rocks. This must be

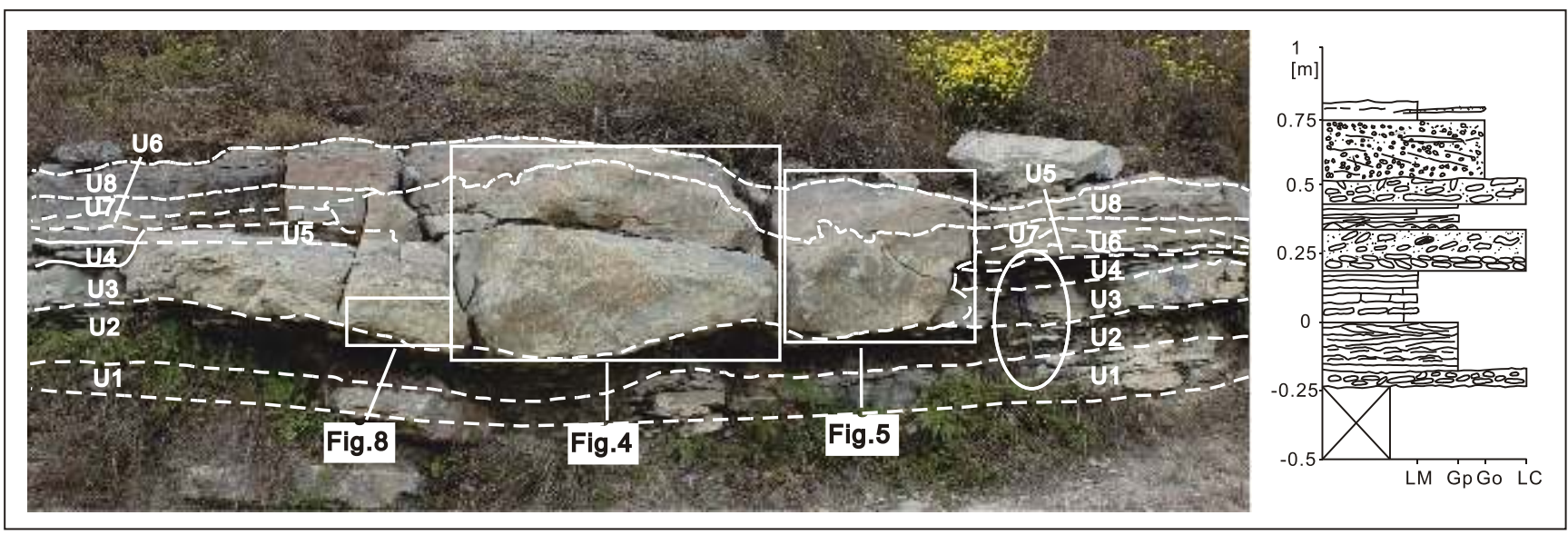

Fig. 3. The conglomerate mass eroded into undeformed deposits that also are present laterally of the mass

The undeformed units U1-U2 underlie the mass; the eroded units U3-U7 are present at both sides of the mass; unit 8 overlies the mass. The various units of the autochthonous succession have different lithologies: U1 - flat-pebble conglomerate with lime-mudstone clasts that are rounded, poorly sorted and mostly horizontal, embedded in a grainy matrix; U2 - thin-bedded peloidal grainstone with low-angle cross-lamination; U3 - thin-bedded $(\sim 1 \mathrm{~cm})$ lime-mudstone in the upper part, argillaceous lime-mudstone in the lower part; U4 - layer with mostly rounded, horizontally positioned, homogeneous and laminated clasts that become less frequent upwards, embedded in a grainy matrix, and capped by cross-laminated lime-mudstone; U5 - laminated peloidal grainstone with a thin shale; U6 - layer with mostly rounded lime-mudstone clasts in a grainy matrix, with a sharp erosional upper surface; U7 - cross-laminated oolite; (U8) cross-laminated oolite, with disconnected lime-mudstone layers. The average thicknesses of the various units in the section are indicated in the sedimentary log at the right; see hammer for scale (shown in oval) 


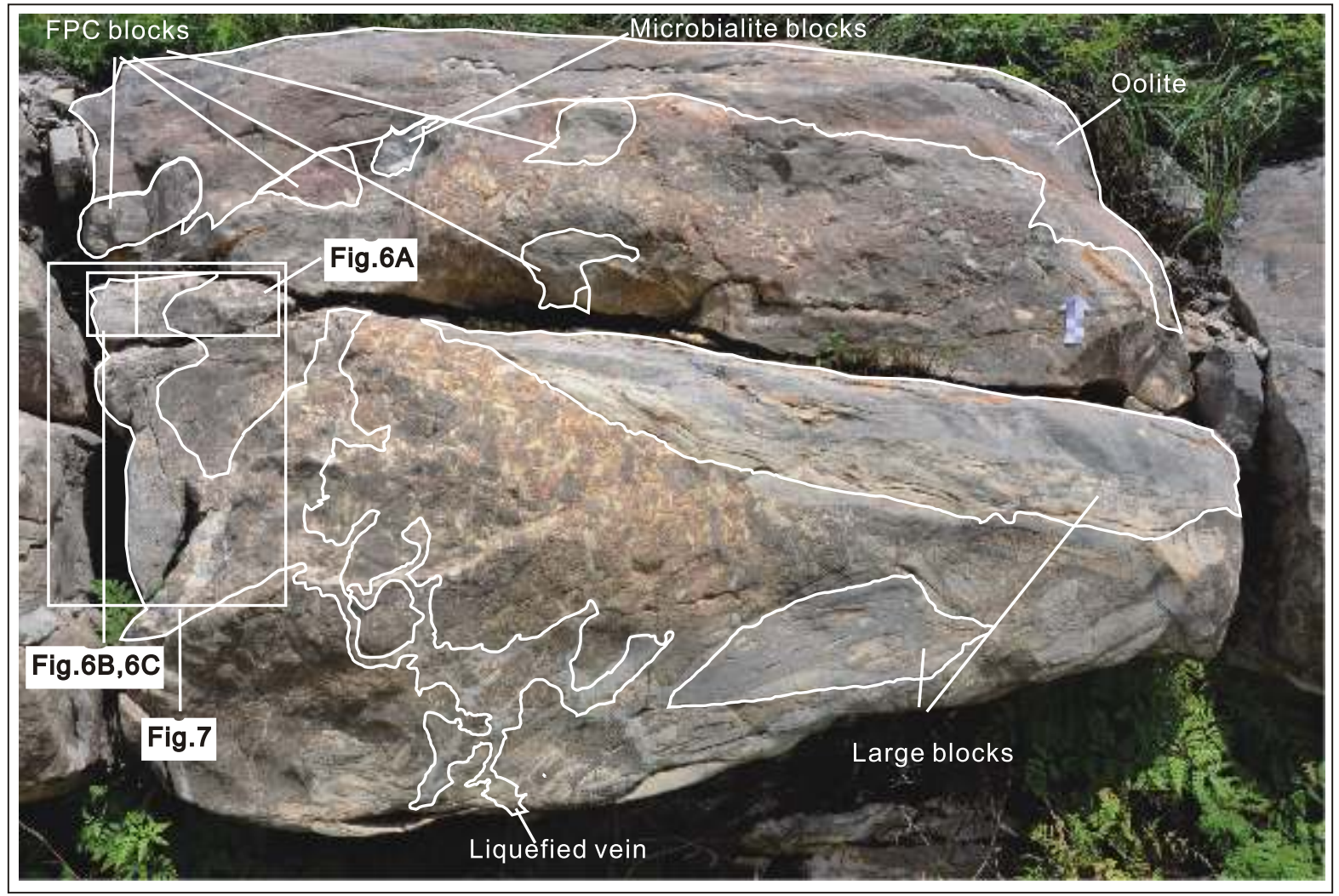

Fig. 4. Left-hand part of the conglomerate mass (see Fig. 3 for position), showing the unsorted character with boulder-sized fragments of different lithologies, and irregular vein-like structures formed by the escape of fluidized water/sediment mixtures

Note the unsorted character of the dyke infillings, and the large size of the fragments in it

ascribed to zones of weakness that originated when the structure was formed.

The structure consists of clasts within a lime-mud matrix, which lithology is completely different from the conglomerate mass at its right side and the flat-pebble conglomerate at its left side. The clasts have shapes that range from angular to rounded; most seem to represent fragments that have been transported in a lithified or semi-lithified state, but some fragments have a slightly bent shape that suggests deformation during a consolidated but not yet lithified state; this bending may have occurred before or after the final transport.

The most remarkable is the sorting in the funnel-shaped structure: although fine clasts ( $\mathrm{mm}$ size) occur throughout the structure, larger clasts become more common upwards. The overall upward increase is clast size is accompanied by an equally overall upward trend of the clasts to become more angular.

Lateral Breccia Injectite - a clastic dyke extends laterally from the conglomerate mass toward the left. It consists of clasts embedded in lime-mud (Fig. 8). The width of the vein is $\sim 5 \mathrm{~cm}$ and the visible length of the dyke is some $80 \mathrm{~cm}$. The clasts are mostly orientated sub-parallel to the bedding, i.e., sub-parallel to the walls of the dyke. The occurrence of this dyke is remarkable because of its bed-parallel position (Fig. 8). Other dykes and veins, which are common in the Gushan Fm., tend to be roughly vertical.

\section{INTERPRETATION}

The conglomerate mass under study differs fundamentally from the numerous other conglomerates that occur in this formation and the overlying Chaomidian Formation. The most important differences are:

- it does not constitute a layer that extends laterally over hundreds of metres or more without significant changes in characteristics,

- it has a strongly erosional base in the form of a narrow channel,

- the upper boundary is highly irregular, with clasts extending above the average level,

- the clasts are polymict, whereas other conglomerates and breccias in this formation tend to be monomict,

- huge clasts with visible lengths of several decimetres (up to $90 \mathrm{~cm}$ ) are present,

- no sorting is present in the deposit as an entity,

- the elongated clasts do not show any preferred orientations.

The above properties cannot be explained as a result of the processes that prevail in an epeiric sea where lime-mud is the main sediment, and where the resulting argillaceous limestones are, sometimes before and sometimes after lithification, broken up by wave activity, resulting in breccias that may be transported over longer or shorter distances to form breccias or con- 


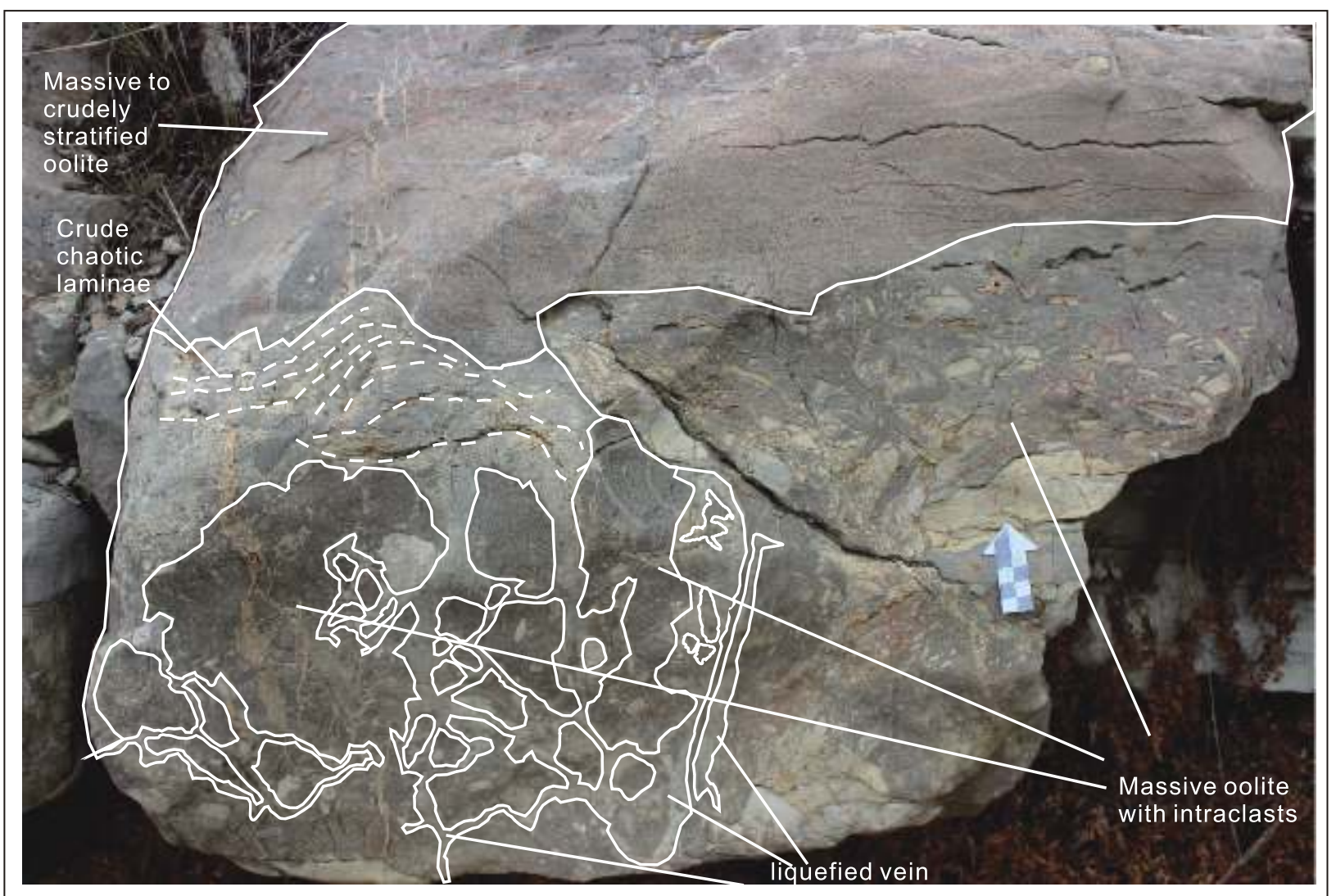

Fig. 5. Right-hand part of the conglomerate mass, with large clasts and numerous irregular escape structures

glomerates. It should be mentioned here that we will use the term "breccia" in the following for the sake of brevity, even though part of the clasts may be rounded, because most clasts are angular. The underlying processes that formed the "normal" conglomerates and breccias in the overlying Chaomidian Fm., which is very well comparable with the Gushan Fm. regarding the sedimentary environment and the processes that were active during and after accumulation, have been dealt with in detail earlier (Van Loon et al., 2013).

The occurrence of a mixture of non-oriented pebbles and even boulders within a fine-grained matrix (the sediment under study might consequently be called a diamictite) can be explained feasibly only in a few ways if exceptional (and obviously not applicable) occurrences such as gastroliths in a lacustrine sediment or glacial dropstones in a deep sea are excluded. The two common processes that can result in such deposits are glacial activity (resulting in glacial tills) and mass flows. A glacial origin can be excluded for several reasons:

- no glaciation is known to have occurred in this region during this time-span in spite of numerous detailed investigations;

- a glaciation would have left deposits over a much wider extent than a few metres;

- none of the clasts show glacial striae. This leaves an origin by mass flow as the only feasible explanation.

\section{ANALYSIS OF MASS-FLOW TYPES}

Mass flows may take numerous forms, ranging from high water/sediment ratios to low ones, forming hyperpycnal flows,

Types of clasts in the conglomerate mass

\begin{tabular}{|c|c|}
\hline Clast type & Description \\
\hline $\begin{array}{l}\text { Homogeneous } \\
\text { lime- mudstone clasts } \\
\text { (LMC) }\end{array}$ & slightly reddish or brown rim, rounded to subrounded, partly angular, up to a few mm to 3-4 in size \\
\hline $\begin{array}{l}\text { Oolite clasts } \\
(\mathrm{OC})\end{array}$ & $\begin{array}{l}\text { rounded to subrounded with distinct boundaries; some clasts with relatively vague boundaries, } \\
\text { within clotted/laminated white wacke }\end{array}$ \\
\hline $\begin{array}{l}\text { Clotted/brecciated } \\
\text { wacke clasts } \\
\text { (CWC) }\end{array}$ & clotted/brecciated white wacke, within similar material, subrounded to subangular, vague boundaries \\
\hline $\begin{array}{l}\text { Conglomerate clasts } \\
\text { (CC) }\end{array}$ & $\begin{array}{c}\text { sharp boundaries; boulders of flat-pebble conglomerate and overlying laminated wacke } \\
\text { to packstone, up to } 90 \mathrm{~cm} \text {; blocks of white microbialite and trilobite-rich microbialite; } \\
\text { boulders with red-rimmed fragments }\end{array}$ \\
\hline
\end{tabular}



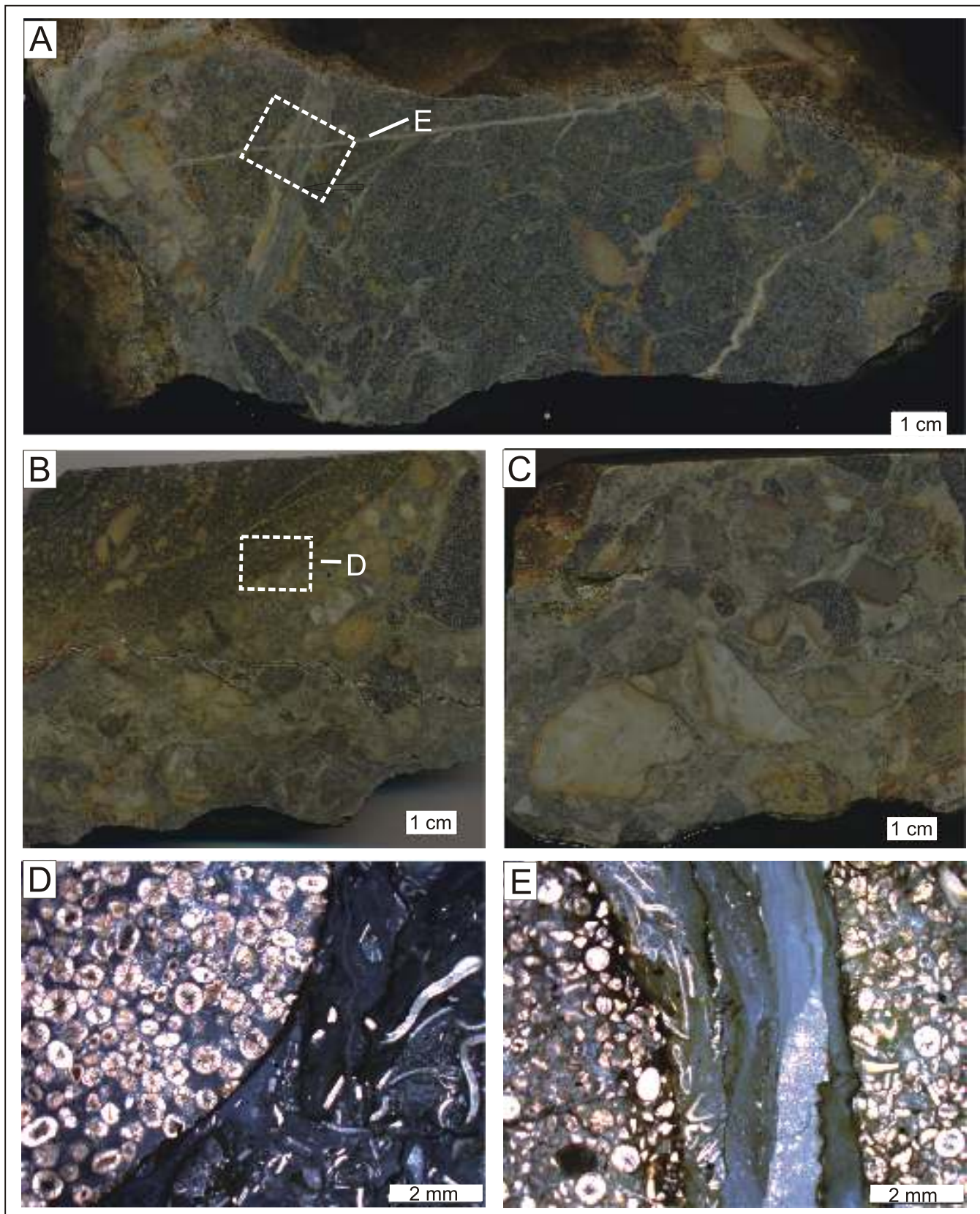

Fig. 6. Polished slabs and photomicrographs of the conglomerate mass

A - the fluid-escape structure in the oolites; $\mathbf{B}$ - boundary between oolite and bioclastic lime-mudstone; $\mathbf{C}$ - overview of different types of clasts (for position, see Fig. 4); $\mathbf{D}$ - sharp boundary between oolite and bioclastic limestone under the microscope; $\mathbf{E}$ - fluid-escape structure with bioclasts penetrating and crushing an oolite

turbidity currents, low-density and high-density debris flows, and slumps in order of decreasing ratios. Each of these flows results in deposits with specific characteristics, but the sediment under study shows a mixture of characteristics. It must therefore be assumed that the mass flow has undergone transitions from one type into another during transport.

The external shape of the deposit, which looks more or less ball-shaped as far as can be deduced from the exposed part (Fig. 3), suggests that the deposit came to rest when it was a slump. Such a nature would also be consistent with the erosional structure in which the sediment mass came to rest: the higher the sediment/ratio, the more downward erosive capability. A debris flow would more easily have spread out over a wide area, rather than be restricted to a channel-like erosional form of only $2.3 \mathrm{~m}$ wide. Another argument in favour of a slump character when the sediment mass came to rest is the highly irregular upper surface (Fig. 3), where several clasts stick out above the average upper boundary up to several centimetres; this cannot be explained as an erosional feature, as the spaces between these clasts have become filled up with the same oolite that was deposited before this mass-flow event took place and that continued afterwards without interruption, as can be deduced from the sedimentary succession alongside the mass-flow deposit under study.

The internal texture of the sediment mass can, however, not be explained as a result of transport in the form of a subaque- 

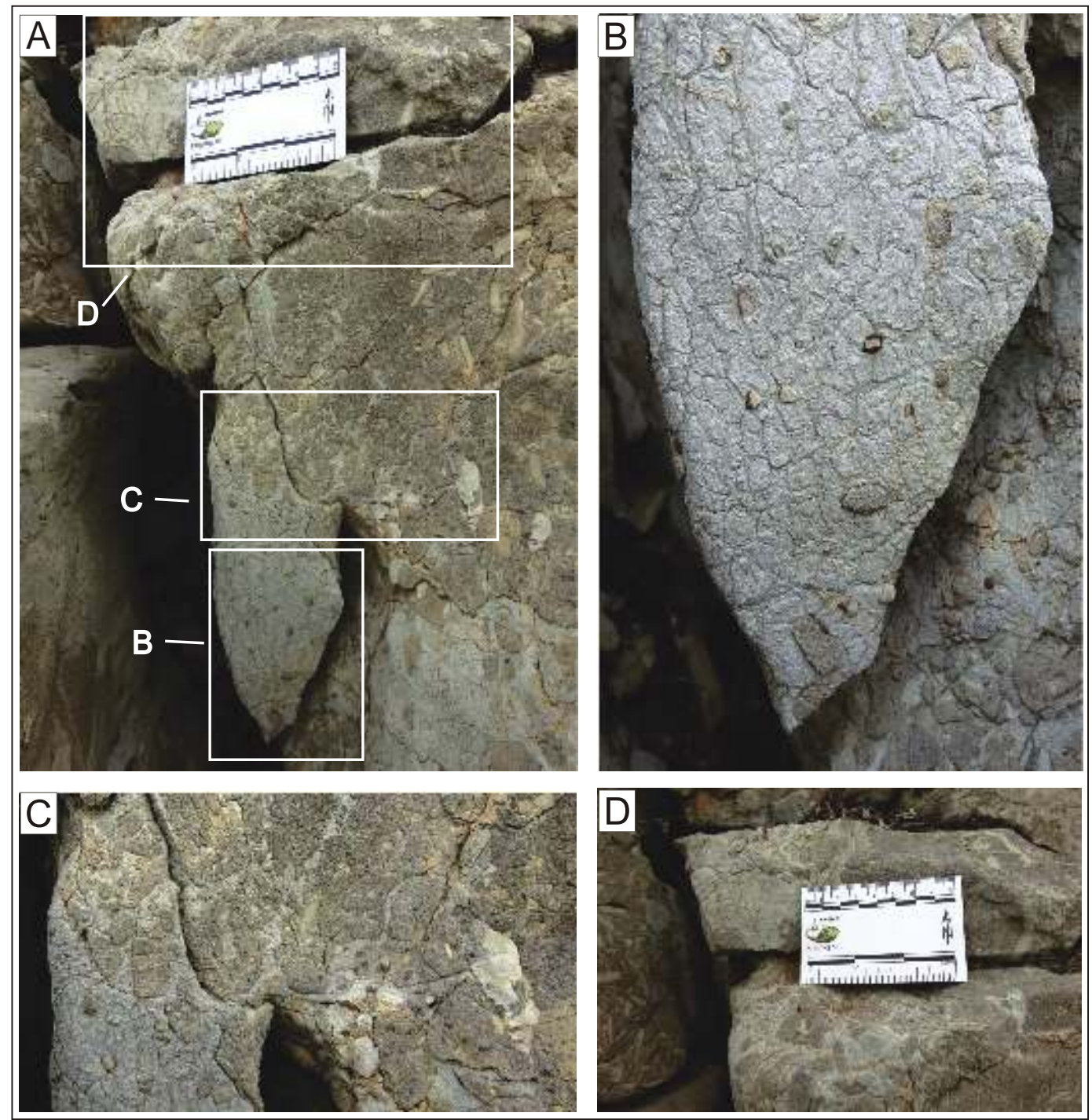

Fig. 7. The funnel-shaped escape structure at the left-hand side of the conglomerate mass (for position, see Fig. 3)

A - overview of the structure; B - detail of its lower part, showing the relatively small fragments in a dense packing; $\mathbf{C}$ - detail of the middle part with on average larger fragments and more finer-grained matrix material; $\mathbf{D}$ - detail of the top part with the largest fragments and more matrix

ous slump. There are no traces of original bedding left, clasts with widely varying lithologies are present, and large boulders of up to $90 \mathrm{~cm}$ float apparently haphazardly in the unit under study (Fig. 4). These characteristics point at transport in the form of a high-density debris flow that picked up material from the successive layers over which it ran down. This explains not only the different clast types, but also the different shapes of the clasts involved: some are bent, indicating a consolidated but non-lithified state, others were apparently eroded as lithified material, and the partly fine-grained matrix shows that most likely also hardly consolidated sediments became involved in the debris flow. It thus must be concluded when the considerations of the previous paragraph are also taken into account, that a high-density flow existed that transformed into a slump before coming to rest.

It is not likely, however, that sediments deposited on a carbonate platform in an epeiric sea start moving in the form of a high-density flow. The uppermost sedimentary succession must have consisted of an alternation of lime-mud, oolitic sediments, and broken up limestones - all probably with a combination of still water-saturated, slightly consolidated, strongly consolidated, slightly lithified and completely lithified layers. Such a succession will, particularly in cases like a tectonically quiet epeiric sea where the sedimentary surface shows maximally a slope of a few degrees, not likely start to move in the form of a high-density debris flow: there is just a too large abundance of pore water. It is well-possible, however, that ongoing rapid sedimentation - and this was probably the case as indicated by centimetre- and even decimetre-scale foresets suggesting rapid accumulation - led to slope failure. A sediment that thus becomes released from its substratum tends initially to slide down, then becoming gradually disturbed by the friction with the bottom over which it slides down. This friction leads to bending of plastic (= consolidated and semi-consolidated) layers, which thus take the form of a slump mass. Such a slump mass gains momentum while moving downslope, thus becoming capable of 


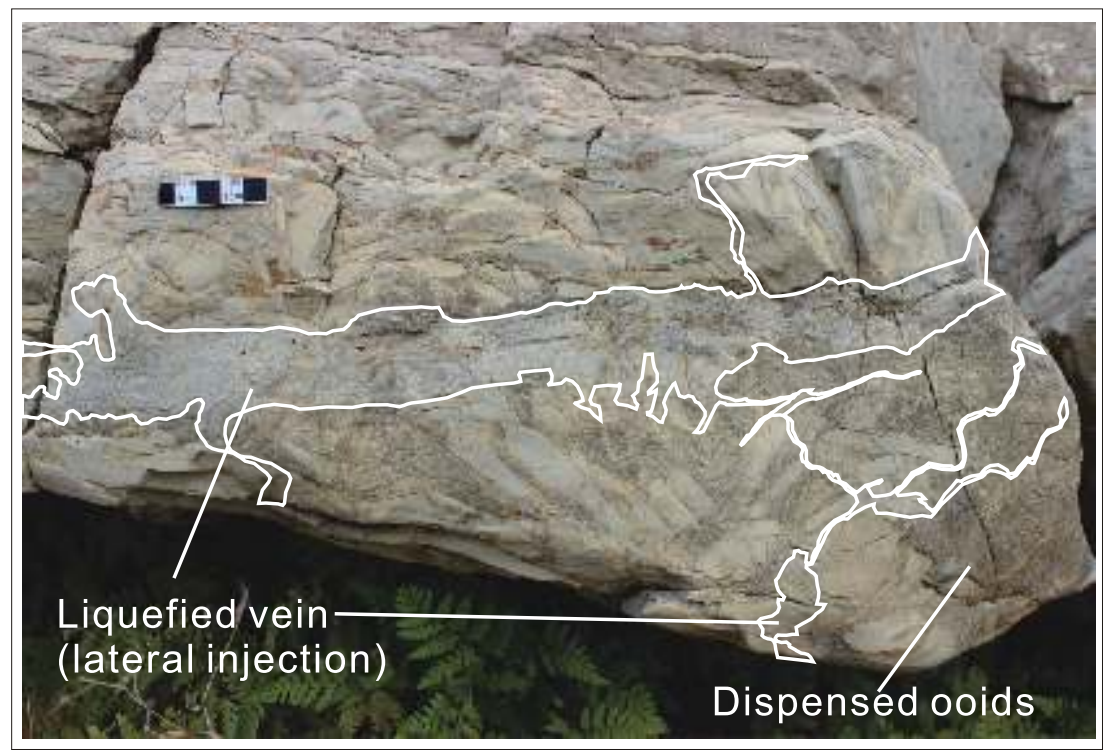

Fig. 8. The lateral injection (for position see Fig. 3)

Note its irregular character, which must be ascribed to the inhomogeneous lithology of the penetrated flat-pebble conglomerate

eroding sediments of the substratum on its pathway, which increases the water/sediment ratio. If this proceeds, the slump transforms into a high-density flow in which the eroded clasts become haphazardly distributed. Only when the slope diminishes and the debris flow slows down sufficiently (but gradually), it may transform again into a slump.

The above sequence of changes implies that, like in some other cases mentioned in the literature (e.g., Tournadour et al., 2015; Sobiesiak et al., 2016; Carvalho and Vesely, 2017), slope failure led to a mass flow that changed from a sliding mass into a slump, then into a high-density flow and eventually again to a slump, in which state the mass came to rest. A detailed analysis of such transitions was provided by Strachan (2008) for the Early Miocene Little Manly Slump in the Waitemata Basin, New Zealand; our findings resemble his example in many respect, though we did not find any evidence of a transformation of the gravity flow into a turbidity current, which must have occurred in the New Zealand example.

\section{ORIGIN OF THE FUNNEL-SHAPED STRUCTURE}

The funnel-shaped structure described in Section 3.3.1 has characteristics that are almost identical to those mentioned by Chen et al. (2009b), also from Cambrian limestones in Shandong Province. We therefore refer to their study for details, and only mention the most relevant aspects and conclusions.

The funnel structure represents a special type of clastic dyke. It was formed by the intrusion of pore water and/or fluidized material from the underlying sediment that became over-pressurized under the influence of the suddenly increased weight of the slump mass. The fluidized sediment started to escape upwards (into the direction of the lowest lithostatic pressure) through a narrow zone of weakness in the adjacent limestone layer, forming a narrow conduit in the lower part. Due to the energy of the escaping pore water and fluidized sediment, the walls of the only slightly lithified intruded limestone became fragmented. Consequently, the conduit gradually widened upwards.

These funnel structures represent a type of soft-sediment structure that has been hardly mentioned in the literature, even though we have found several examples of this feature in shallow-marine carbonate deposits.

\section{DEVELOPMENT OF THE LATERAL BRECCIA INJECTITE}

Water-escape structures are common features in the Gushan Fm. because differential consolidation and lithification of lime-mud layers resulted in seals over still water-saturated sediments. All these structures are directed upwards, because the escaping water/sediment mixtures that eventually broke through a sealing layer choose the direction of least (lithostatic) pressure, i.e. toward the sedimentary surface. The lateral injectite described in Section 3.3.2. is therefore an exceptional feature in this formation, and there can be little doubt that its formation was directly related to the mass-flow deposit from which it extends into the adjacent sediment.

The texture of the injectite is remarkable because it does not consist of fine-grained material but of a clast-supported breccia (Fig. 5). Obviously, injection could take place only if the intruding material was in a fluidized state. This implies that fluidization must have occurred at the base of the slump mass. The only feasible explanation for this phenomenon is that the deposition of the slump mass, when the velocity of the slump head decreased and the kinetic energy was no longer sufficient to overcome the friction with the sedimentary substratum, led to a sudden pressure increase of the water-saturated sediments on which it came to rest, so that fluidization took place.

The fluidized material under the slump mass tried to find an escape route into the direction of least resistance. In this case, this was not upwards, as the slump mass was, although partly deposited in the channel that it had eroded itself, so thick that the top part stuck out above the surface of the adjacent sedi- 
mentary succession (see Sections 3.1 and 4). This implies that the lithostatic pressure in a lateral direction was lower than upwards, and consequently the over-pressurized fluidized material injected the neighbouring sediments laterally. Obviously, this must have required a considerable energy, which must have been supplied by the weight of the slump mass.

\section{DISCUSSION}

Carbonate platforms in epeiric seas can develop over immense distances only because the depositional conditions in the entire area are stable. Such conditions are not favourable for the initiation of mass flows, but it should be kept in mind that the basin in which the Gushan Fm. accumulated must have been subsiding: a thick unit of very shallow deposits (including oolites and storm-induced breccias) could accumulate (Fig. 9A); it thus must be concluded that subsidence and sedimentation were in balance. This must have continued for a considerable time, as not only the Gushan Fm. but also the overlying Chaomidian Fm. (with a joint thickness of $\sim 250 \mathrm{~m}$ in the study area) lack any trace of a significant change of the depositional environment. Ongoing subsidence implies instability, whether caused by tectonics or by the weight of the accumulating sediment.
If endogenic tectonics were the process behind the subsidence, it could well be possible that the overall gradual subsidence was occasionally (but rarely) accompanied by some small-scale faulting. Such faulting could have induced small shock waves that were sufficient to trigger the slope failure (Fig. 9B) that initiated the processes described in the present contribution. Such slope failure would have been facilitated by the fairly high sedimentation rate, which had resulted in water-saturated layers (cf. Parker, 1982). If it was the weight of the accumulated sediment that initiated the subsidence (such as commonly is the case in deltaic areas), it is even more likely that the required rapid sedimentation rate induced failure of the slope.

An important question in this context is whether a slope was present, indeed, and whether such a slope - if present - was sufficiently steep to allow mass flows to develop and transform into other types. The first part of the question can be answered easily: if the basin was subsiding, slopes must have originated (unless it is assumed that the whole basin subsided at the same rate due to global-scale tectonics, for which hypothesis no arguments can be found). Moreover, some small bioherms occur at a distance of only some tens of metres away from the site under study; the bioherms are developed at the same or nearly the same stratigraphic level as the mass-flow deposit under study (precise correlation is impossible because terraces have been built for agricultural purposes, which make most of the rocks unexposed). Such bioherms must, due to their irregular outer shapes, also have caused some sloping area on the platform.

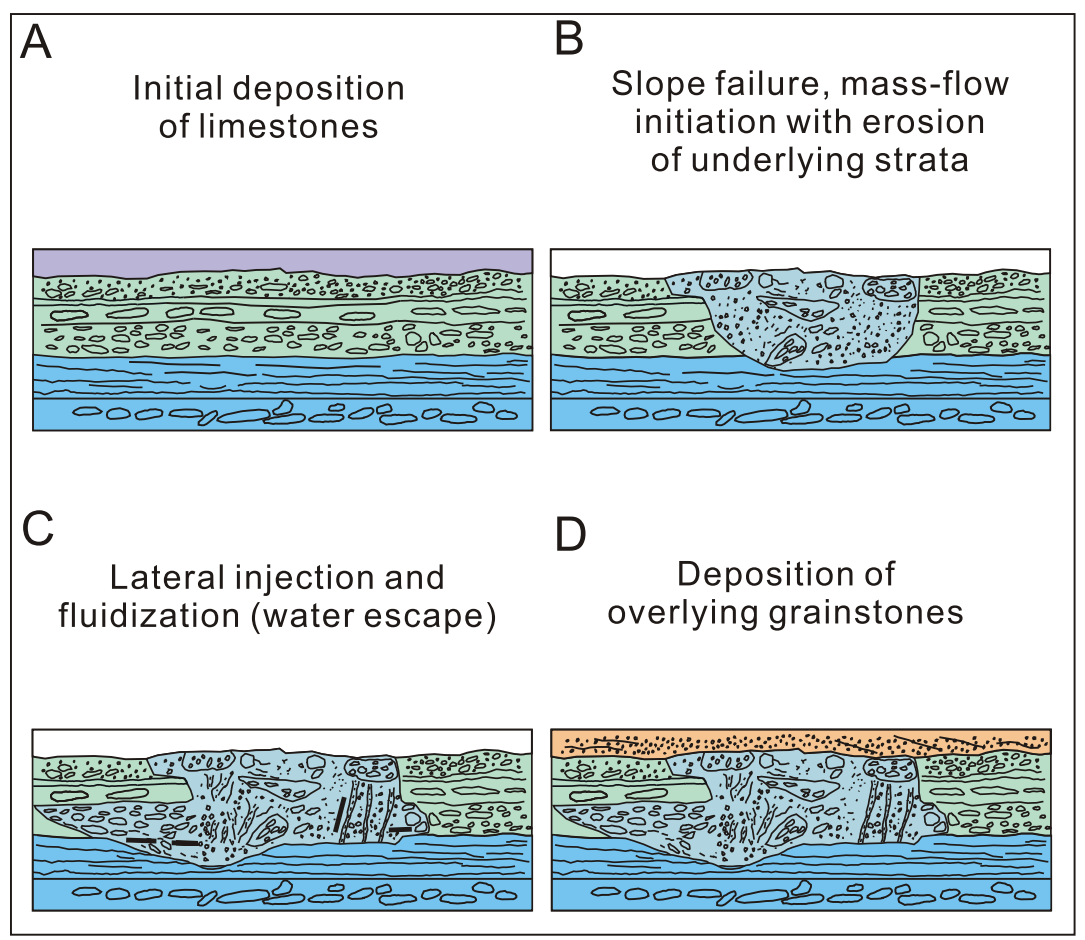

Fig. 9. Schematic model showing the successive processes leading to the position of the chaotic conglomerate/breccia mass within a succession of well-bedded limestones

A - situation before the event; B - slope failure, resulting in an erosional slump that transforms into a high-density gravity flow in which the original stratification is lost, causing a chaotic fabric of unsorted clasts of all types of lithology; $\mathbf{C}$ - deposition of the mass that had transformed back into a slump, causing over-pressurized pore water of the underlying sediments that become fluidized and escape upwards at the side of the slump mass and laterally under the mass; $\mathbf{D}$ - ongoing oolite sedimentation covers the irregular surface of the conglomerate/breccia mass and the adjacent sediments 
The question of whether the slopes that were present beyond any doubt were sufficiently steep to allow mass flows to develop, has already been answered in other studies that mention mass transport in a comparable setting. Pedley et al. (1992), for instance, investigated seismically-induced sliding on a carbonate ramp. It was found frequently that even a very gentle slope is sufficient for mass transport (Gibert et al., 2005; Moretti and Sabato, 2007; Alsop and Marco, 2011). Examples of slumping that must have occurred over near-horizontal sedimentary surfaces (in mainly deltaic and lacustrine environments) have been described several times, also for inclinations of $<1^{\circ}$ (e.g., García-Tortosa et al., 2011) and even $<0.25^{\circ}$ (Field et al., 1982). Very low-angle movement has also been demonstrated experimentally (Owen, 1996). Consequently, mass transport must have been possible at the study site.

The transition from one type of mass transport into another type, as deduced from the characteristics of the mass-flow deposit under study, involves several processes from the slope failure to final deposition (Mulder et al., 2003), but is not exceptional, even in the case of a single event. By gaining momentum during downward flow (Parker et al., 1986), even turbidity currents can result from slide transformation, concentration processes, or a mixture of processes, commonly passing states as a slump and as a debris flow (Middleton and Hampton, 1973, 1976; Lowe, 1979, 1982; Nardin et al., 1979). The transformation of a submarine slide into a flow in which turbulent energy substantively increases (Fig. 9B) has been described by numerous authors from numerous places (e.g., Fukushima et al., 1985), both from ancient deposits and from modern settings, including the 1929 Grand Banks event (Hughes-Clarke, 1990; Piper et al., 1992), and the 1979 Nice event (Malinverno et al., 1988).

The high-density flow transformed into slump again (as can be deduced from its characteristics analysed and detailed in the Interpretation section) when the friction with the gradually less inclined slope became too large so that water was expelled from the mass, and finally the conglomerate mass came to rest. This resulted in a sudden increased pore-water pressure of the lower sediments, causing the vertical escape of fluidized water/sediment mixtures in the form of funnelshaped (and other) clastic dykes at the side of the slumped mass, and in the lateral escape where the weight of the overlying mass resulted in a lithostatic pressure that was higher upwards than laterally (Fig. 9C).

This event was no more than a momentary interruption of the autochthonous sedimentation, which continued in the form of oolite deposition, covering the irregular upper boundary of the conglomerate/breccia mass (Fig. 9D).

Based on the above data from both ancient and modern settings, it must be deduced that the depositional process of the rock unit under study here is not exceptional in itself, but that it is exceptional because it has not been described before from ancient carbonate platforms. This raises the question why similar deposits are not found more frequently in limestone successions that accumulated on carbonate platforms in epeiric seas. An answer to this question must, by definition, be speculative, but we feel that we should propose some possibilities, so as to help future investigators to provide a more founded answer. One reason might be that, if conglomerates are present in Early Paleozoic limestone successions that accumulated on carbonate platforms, they have not been recognized as having an origin that differs from the commonly numerous other material with a diverging lithology (like in our case: see Table 1) may not be present in other successions; carbonate platforms tend to extend over hundreds of kilometres, so that clastic material from elsewhere must be extremely rare. A third reason might be that epeiric seas are commonly considered, on the basis of hundreds of studies, as tectonically stable; consequently, height differences on the platforms are, as a rule, absent or small, so that gravity flows do not originate easily; we cannot exclude that some shock, possibly resulting from an overloading-triggered earthquake, has affected the Gushan succession. Whatever the case, it seems worthwhile to pay attention to this aspect in future studies.

\section{CONCLUSIONS}

A more or less ball-shaped conglomerate in the Middle Cambrian Gushan Formation near Chengouwan (Shandong Province, E China) has so many characteristics that differ from the numerous other conglomerates in this formation that its origin has been studied in detail. The conglomerate contains four types of clasts:

- homogeneous lime-mudstone clasts (LMC),

- oolite clasts (OC),

- clotted/brecciated wackestone clasts (CWC),

- conglomerate clasts (CC).

Moreover, it contains a funnel-shaped escape structure and a large lateral injectite.

The studied unit is interpreted as originated from mass flow and is explained as a deposit consisting of material that was eroded up-slope when slope-failure took place, resulting in a slump that passed into a high-density debris flow with erosive power that passed, in turn, again into a slump. The slump came to rest when it lost its momentum on a less inclined part of the basin slope. The sudden deposition of the slump mass on top of water-saturated sediments caused the latter to liquefy. This resulted in the escape of pore water under high pressure, resulting in the formation of a funnel-shaped escape structure where the pore water could escape upwards alongside the slump mass. Where such an upward escape was impossible because of the overlying slump, the pore water was pressed out sideward, forming a large lateral injectite.

The analysis of the origin of the conglomerate mass shows that, in contrast to what is commonly believed, mass transport could take place on ancient carbonate platforms that developed in an epeiric sea.

Acknowledgements. This study was supported by the National Natural Science Foundation of China (Grant no. 41772095), the Taishan Scholar Talent Team Support Plan for Advanced \& Unique Discipline Areas, the Major Scientific and Technological Innovation Projects of Shandong Province (Grants no. 2017CXGC1602 and 2017CXGC1603), the 2019 Provincial Geological Exploration Project of Shandong Province (Grant no. SDGP370000201902000645), and SDUST Research Fund (Grant no. 2015TDJH101). We gratefully acknowledge J. Chen, D. Lv and Y. Zhao for discussions in the field and laboratory. We also thank an anonymous reviewer and B. Gruszka for their constructive comments that helped improve the manuscript. 


\section{REFERENCES}

Alsop, G.I., Marco, S., 2011. Soft-sediment deformation within seismogenic slumps of the Dead Sea Basin. Journal of Structural Geology, 33: 433-457.

Carvalho, A.H., Vesely, F.F., 2017. Facies relationships recorded in a Late Paleozoic fluvio-deltaic system (Paraná Basin, Brazil): insights into the timing and triggers of subaqueous sediment gravity flows. Sedimentary Geology, 352: 45-62.

Chen, J., 2015. Origin of the Furongian limestone breccias in the North China Platform. Science China Earth Sciences, 58 : 770-775.

Chen, J., Lee, H.S., 2013. Soft-sediment deformation structures in Cambrian siliciclastic and carbonate storm deposits (Shandong Province, China): differential liquefaction and fluidization triggered by storm-wave loading. Sedimentary Geology, 288: 81-94.

Chen, J., Chough, S.K., Chun, S.S., Han, Z., 2009a. Limestone pseudoconglomerates in the Late Cambrian Gushan and Chaomidian Formations (Shandong Province, China): soft-sediment deformation induced by storm-wave loading. Sedimentology, 56: 1174-1195.

Chen, J., Van Loon, A.J., Han, Z., Chough, S.K., 2009b. Funnel-shaped, breccia-filled clastic dykes in the Late Cambrian Chaomidian Formation (Shandong Province, China). Sedimentary Geology, 221: 1-6.

Chen, J., Han, Z., Zhang, X., Fan, A., Yang, R., 2010. Early diagenetic deformation structures of the Furongian ribbon rocks in Shandong Province of China - a new perspective of the genesis of limestone conglomerates. Science China Earth Sciences, 53: 241-252.

Chen, J., Chough, S.K., Han, Z., Lee, J.-H., 2011. An extensive erosion surface of a strongly deformed limestone bed in the Gushan and Chaomidian Formations (late Middle Cambrian to Furongian), Shandong Province, China: sequence-stratigraphic implications. Sedimentary Geology, 233: 129-149.

Chen, J., Chough, S.K., Lee, J.-H., Han, Z., 2012. Sequence-stratigraphic comparison of the upper Cambrian Series 3 to Furongian succession between the Shandong region, China and the Taebaek area, Korea: high variability of bounding surfaces in an epeiric platform. Geosciences Journal, 16: 357-379.

Chen, J., Lee, J.-H., Woo, J., 2014. Formative mechanisms, depositional processes, and geological implications of Furongian (Late Cambrian) reefs in the North China Platform. Palaeogeography, Palaeoclimatology, Palaeoecology, 414: 246-259.

Chough, S.K., Lee, H.S., Woo, J., Chen, J., Choi, D.K., Lee, S.-B., Kang, I., Park, T.-Y., Han, Z., 2010. Cambrian stratigraphy of the North China Platform: revisiting principal sections in Shandong Province, China. Geosciences Journal, 14: 235-268.

Field, M.E., Gardner, V., Jennings, A.E., Edwards, B.D., 1982. Earthquake-induced sediment failures on a $0.25^{\circ}$ slope, Klamath river delta, California. Geology, 10: 542-546.

Fukushima, Y., Parker, G., Pantin, H.M., 1985. Prediction of ignitive turbidity currents in Scripps submarine canyon. Marine Geology, 67: 55-81.

García-Tortosa, F.J., Pedro Alfaro, P., Gibert, L., Scott, G., 2011. Seismically induced slump on an extremely gentle slope $\left(<1^{\circ}\right)$ of the Pleistocene Tecopa paleolake (California). Geology, 39 : $1055-1058$

Gibert, L., Sanz de Galdeano, C., Alfaro, P., Scott, G., Lopez Garrido, A.C., 2005. Seismic induced slump in Early Pleistocene deltaic deposits of the Baza Basin (SE Spain). Sedimentary Geology, 179: 279-294.

Han, Z., Zhang, X., Chi, N., Han, M., Woo, J., Lee, H., Chen, J., 2015. Cambrian oncoids and other microbial-related grains on the North China Platform. Carbonates and Evaporites, 30: 373-386.

Hughes-Clarke, J.E., 1990. Late stage slope failure in the wake of the 1929 Grand Banks earthquake. Geo-Marine Letters, 10: $69-79$.
Lee, H.J., Chough, S.K., Chun, S.S., Han, S.J., 1991. Plateau slope, sediment failure on the Korea Plateau slope, East Sea (Sea of Japan). Marine Geology, 97: 363-377.

Lee, H.S., Chough, S.K., 2011. Depositional processes of the Zhushadong and Mantou Formations (Early to Middle Cambrian), Shandong Province, China: roles of archipelago and mixed carbonate-siliciclastic sedimentation on cycle genesis during initial flooding of the North China Platform. Sedimentology, 58: 1530-1572.

Lee, H.S., Chen, J., Han, Z., Chough, S.K., 2018. Depositional processes and environmental changes during initial flooding of epeiric platform: Liguan Formation (Cambrian Series 2), Shandong Province, China. Geosciences Journal, 22: 903-919.

Locat, J., Mienert, J. eds., 2003. Submarine Mass Movements and their Consequences. Kluwer Academic Publishers, Dordrecht.

Lowe, D.R., 1979. Sediment gravity flows: their classification and some problems of application to natural flows and deposits. SEPM Special Publication, 27: 75-82.

Lowe, D.R., 1982. Sediment gravity flows: II. Depositional models with special reference to the deposits of high-density turbidity currents. Journal of Sedimentary Petrology, 52: 279-297.

Lu, Y.H., Dong, N.T., 1952. Revision of the Cambrian type sections of Shantung (in Chinese). Acta Geologica Sinica, 3: 164-201.

Ma, Y., Mei, M., Zhou, R., 2017. Forming patterns of an oolitic bank within a sequence-stratigraphic framework: an example from the Cambrian Series 3 in the Xiaweidian section in the Western Suburb of Beijing (in Chinese with English summary). Acta Petrologica Sinica, 33: 1021-1036.

Malinverno, A., Ryan, W.B.F., Auffret, G.A., Pautot, G., 1988. Sonar images of the path of recent failure events on the continental margin off Nice, France. GSA Special Paper, 229: 59-75.

Mei, M., Ma, Y., Mei, S., Hu, J., 1997. Framework of a Cambrian sedimentary succession and evolution of the carbonate platform in North China (in Chinese). Geoscience, 3: 275-282.

Meng, X., Ge, M., Tucker, M.E., 1997. Sequence stratigraphy, sea-level changes and depositional systems in the Cambro-Ordovician of the North China carbonate platform. Sedimentary Geology, 114: 189-222.

Middleton, G.V., Hampton, M.A., 1973. Sediment gravity flows: mechanics of flow and deposition. In: Turbidites and Deep-water Sedimentation (eds. G.V. Middleton and A.H. Bouma): 1-38. SEPM Pacific Section.

Middleton, G.V., Hampton, M.A., 1976. Subaqueous sediment transport and deposition by sediment gravity flows. In: Marine Sediment Transport and Environmental Management (eds. D.J. Stanley and D.J.P. Swift): 197-218. Wiley, New York.

Mienert, J., Weaver, P.P.E. eds., 2002. European Margin Sediment Dynamics, Side-Scan Sonar and Seismic Images. SpringerVerlag, Berlin.

Moretti, M., Sabato, L., 2007. Recognition of trigger mechanisms for soft-sediment deformation in the Pleistocene lacustrine deposits of the Sant'Arcangelo Basin (southern Italy): seismic shock vs. overloading. Sedimentary Geology, 196: 31-45.

Mulder, T., Syvitski, J.P.M., Migeon, S., Faugčres, J.-C., Savoye, B., 2003. Marine hyperpycnal flows: initiation, behavior and related deposits. A review. Marine and Petroleum Geology, 20: 861-882.

Myrow, P.M., Chen, J., 2015. Estimates of large magnitude Late Cambrian earthquakes from seismogenic soft-sediment deformation structures: Central Rocky Mountains. Sedimentology, 62: 621-644.

Nardin, T.R., Hein, F.J., Gorsline, D.S., Edwards, B.D., 1979. A review of mass movement processes and acoustic characteristics, and contrasts in slope and base-of-slope systems versus canyon-fan-basin floor systems. SEPM Special Publication, 27: 61-73. 
Owen, G., 1996. Experimental soft-sediment deformation: structures formed by the liquefaction of unconsolidated sands and some ancient examples. Sedimentology, 43: 279-293.

Parker, G., 1982. Conditions for the ignition of catastrophically erosive turbidity currents. Marine Geology, 46: 307-327.

Parker, G., Fukushima, Y., Pantin, H.M., 1986. Self-accelerating turbidity currents. Journal of Fluid Mechanics, 171: 145-181.

Pedley, H.M., Cugno, G., Grasso, M., 1992. Gravity slide and resedimentation processes in a Miocene carbonate ramp, Hyblean Plateau, southeastern Sicily. Sedimentary Geology, 79: 189-202.

Piper, D.J.W., Cochonat, P., Ollier, G., Le Drezen, E., Morrison, M., Baltzer, A., 1992. Evolution progressive d'un glissement rotationnel en un courant de turbidité: cas du séisme de 1929 des Grands Bancs (Terre Neuve). Comptes Rendus de l'Academie des Sciences, Paris, 314, Série II: 1057-1064.

Sobiesiak, M.S., Kneller, B., Alsop, G.I., Milana, J.P., 2016. Internal deformation and kinematic indicators within a tripartite mass transport deposit, NW Argentina. Sedimentary Geology, 344 364-381.

Strachan, L.J., 2008. Flow transformations in slumps: a case study from the Waitemata Basin, New Zealand. Sedimentology, 55 1311-1332

Sultan, N., Cochonat, P., Canals, M., Cattaneo, A., Dennielou, B., Haflidason, H., Laberg, J.S., Long, D., Mienert, J., Trincardi, F., Urgeles, R., Vorren, T.O., Wilson, C., 2004. Triggering mechanisms of slope instability processes and sediment failures on continental margins: a geotechnical approach. Marine Geology, 213: 291-321.

Tian, H., Ma, Y., Di, M., 1994. Storm deposits of Gushan and Changshan formations at Panchegou region of Xintai in Shan- dong Province (in Chinese). Journal of China University of Petroleum, 18: 8-13.

Tournadour, E., Mulder, T., Borgomano, J., Hanquiez, V., Gillet, H., 2015. Origin and architecture of a mass transport complex on the northwest slope of Little Bahama Bank (Bahamas): relations between off-bank transport, bottom current sedimentation and submarine landslides. Sedimentary Geology, 317: 9-26.

Van Loon, A.J., Han, Z., Han, Y., 2012. Slide origin of breccia lenses in the Cambrian of the North China Platform: new insight into mass transport in an epeiric sea. Geologos, 18: 223-235.

Van Loon, A.J., Han, Z., Han, Y., 2013. Origin of the vertically orientated clasts in brecciated shallow-marine limestones of the Chaomidian Formation (Furongian, Shandong Province, China). Sedimentology, 60: 1059-1070.

Wang, L., 1995. The stratigraphic significance of the astronomical period and the storm function of Late Cambrian in North China (in Chinese). Journal of Hebei College of Geology, 18: 328-333.

Wang, Y.H., Zhang, X.L., Yang, C.Y., 1989. Carbonate Petrology of the Early Paleozoic in the North China Platform (in Chinese). Beijing: Earthquake Publishing House: 1-50.

Yang, R., Van Loon, A.J., Jin, X., Jin, Z., Han, Z., Fan, A., Liu, Q. 2019. From divergent to convergent plates: Resulting facies shifts along the southern and western margins of the Sino-Korean Plate during the Ordovician. Journal of Geodynamics, 129: 149-161.

Zhen, Y., Zhang, Y. Wang, Z., Percival, I., 2016. Huaiyuan epeirogeny - shaping Ordovician stratigraphy and sedimentation on the North China Platform. Palaeogeography, Palaeoclimatology, Palaeoecology, 448: 363-370. 